\title{
Optimasi Geometri Jaring GNSS dan RTS untuk Pemantauan Deformasi Kontinu Saluran Induk Kalibawang di Jembatan Talang Bowong, Kabupaten Kulon Progo
}

\author{
(Geometric Optimization of GNSS and RTS Network for Continuous Deformation Monitoring of \\ Kalibawang Irrigation Channel in the Talang Bowong Bridge, Kulon Progo District)

\section{Ghea Ayunda Siami' ${ }^{1}$ Bilal Ma'ruf ${ }^{2}$, Dedi Atunggal ${ }^{2}$} \\ ${ }^{1}$ Alumni Departemen Teknik Geodesi, Fakultas Teknik, Universitas Gadjah Mada, Yogyakarta, Indonesia \\ 2 Dosen Departemen Teknik Geodesi, Fakultas Teknik, Universitas Gadjah Mada, Yogyakarta, Indonesia
}

\author{
Penulis Korespondensi: Bilal Ma'ruf | Email: bilal.maruf@ugm.ac.id
}

\begin{abstract}
ABSTRAK
Kegiatan rehabilitasi dan pemeliharaan di Jembatan Talang Bowong membutuhkan pemantauan gerakan massa tanah secara realtime dan kontinu. Penelitian ini berusaha mendesain jaring kontrol pemantauan gerakan massa tanah secara geometrik dengan data simulasi yang diturunkan dari data orthophoto sebagai langkah awal untuk pembangunan jaring kontrol pemantauan. Data simulasi yang didapatkan berupa koordinat distribusi titik kontrol kemudian diturunkan menjadi vektor baseline. Nilai ketelitian pada penelitian ini didapatkan dari alat yang digunakan pada saat pemantauan berlangsung yaitu GNSS Leica seri GM30 dan RTS Leica seri TS16 1". Jaring kontrol pemantauan didesain berdasarkan integrasi antara GNSS dan RTS. Pembuatan desain jaring kontrol GNSS dilakukan dengan membentuk jaring dengan baseline yang sederhana hingga kompleks. Sedangkan, pembuatan desain jaring kontrol RTS dilakukan berdasarkan variasi jarak antar titik prisma target. Nilai matriks varian-kovarian pengamatan dari estimasi hitung kuadrat terkecil digunakan untuk pemilihan desain geometri jaring terbaik berdasarkan hasil perhitungan kriteria presisi yang terdiri atas kriteria A-Optimality, D-Optimality, E-Optimality, S-Optimality, dan I-Optimality. Nilai matriks kofaktor residu digunakan untuk pemilihan desain geometri jaring terbaik berdasarkan kriteria keandalan yang terdiri atas aspek redundansi individu, keandalan dalam, dan keandalan luar. Hasil penelitian menunjukkan bahwa desain jaring GNSS yang paling optimal yaitu jaring DG04. Hal ini ditunjukkan dari nilai kriteria presisi dan keandalan luar paling kecil serta nilai kriteria redundansi individu paling besar. Desain jaring RTS yang paling optimal yaitu jaring rts01. Hal ini ditunjukkan dari nilai kriteria presisi, keandalan dalam, dan keandalan luar paling kecil serta nilai kriteria redundansi individu paling besar.
\end{abstract}

Kata Kunci: optimasi geometri, presisi, keandalan, jaring GNSS, jaring RTS, Jembatan Talang Bowong

\begin{abstract}
Rehabilitation and maintenance activities at the Talang Bowong Bridge require real-time and continuous monitoring of soil mass movements. This research attempts to design a control network for monitoring the soil mass movements geometrically using simulation data derived from orthophoto data as a first step for building a monitoring control network. The simulation data obtained in the form of the distribution coordinates of the control points are then reduced to a baseline vector. The accuracy value in this study was obtained from the tools to be used during monitoring, namely the Leica GNSS GM30 and RTS Leica TS16 1" series. The monitoring control network is designed based on the integration between GNSS and RTS. The design of the GNSS control network is made by forming a network with a simple to complex baseline. While the design of the RTS control network is carried out based on variations in the distance between the target prism points. The value of the observed covariance-variance matrix from the estimated least-squares calculation is used to select the optimal geometry design based on the computation results of precision criteria consisting of the A-Optimality, D-Optimality, EOptimality, S-Optimality, and I-Optimality criteria. In addition, the residual cofactor matrix value is used to select the optimal geometry design based on reliability criteria consisting of redundancy criteria, internal reliability, and external reliability. The results showed that the most optimal GNSS network design was the DG04 network. This is indicated by the smallest precision, external reliability criteria values, and the largest redundancy criteria values. On the other hand, the most optimal RTS network design was the rts01 network. This is indicated by the smallest precision, internal reliability, external reliability criteria values and the largest redundancy criteria values.
\end{abstract}

Keywords: geometric optimization, precision, reliability, GNSS network, RTS network, Talang Bowong Bridge

(c) Author(s) 2021. This is an open access article under the Creative Commons Attribution-ShareAlike 4.0 International License (CC BY-SA 4.0). 


\section{Pendahuluan}

Menurut Dinas Pekerjaan Umum Perumahan dan Kawasan Permukiman (DPUPKP) Kabupaten Kulon Progo, Saluran Induk Kalibawang merupakan saluran utama dalam penyediaan air irigasi di Kabupaten Kulon Progo yang memiliki fungsi untuk mengalirkan air dari bangunan utama ke saluran sekunder. Berdasarkan kondisi geologi, Saluran Induk Kalibawang memiliki kondisi tanah yang tergolong tidak stabil, sehingga mempengaruhi stabilitas bangunan yang berada di sekitar saluran tersebut (DPUPKP, 2020). Segmen km 15,9 merupakan salah satu segmen saluran yang rawan mengalami kerusakan (Ma'ruf, 2015) Kerusakan di segmen km 15,9 ditandai dengan rusaknya bangunan sekolah dasar, jembatan, saluran, dan retaknya talang irigasi (Dwidjaka, 2006). Kerusakan ini diduga diakibatkan adanya pergerakan massa tanah (deformasi) di sekitar segmen $\mathrm{km}$ 15,9. Jembatan Talang Bowong merupakan salah satu bangunan vital yang berada di segmen km 15,9 Saluran Induk Kalibawang. Kegiatan pemantauan diperlukan untuk kepentingan rehabilitasi dan pemeliharaan Jembatan Talang Bowong. Hal ini untuk memprediksi adanya fenomena-fenomena yang terjadi serta meminimalkan adanya kerusakan jembatan akibat pergerakan massa tanah di sekitar segmen $\mathrm{km} \mathrm{15,9.}$

Ma'ruf (2015) melakukan pemodelan analisis deformasi dinamis berdasarkan koordinat titik kontrol pemantauan dengan data infiltrasi hujan yang diselesaikan dengan teknik Kalman Filtering untuk memprediksi gerakan rayapan tanah di segmen $\mathrm{km} 15,9$ Saluran Induk Kalibawang. Penelitian tersebut dilakukan dengan GNSS statik secara periodik dengan interval waktu tertentu. Kegiatan pemantauan gerakan massa tanah dibutuhkan jaring kontrol pemantauan real-time dan kontinu supaya didapatkan data titik koordinat dengan ketelitian yang tinggi di setiap waktu (Leick dkk., 2012). Hal itu berarti dalam kegiatan pemantauan gerakan massa tanah di segmen km 15,9 perlu dilakukan secara real-time dan kontinu untuk mendapatkan data dengan ketelitian yang tinggi. Penelitian ini menggunakan titik kontrol yang digunakan untuk pengambilan data orthophoto serta tinggi titik yang digunakan yaitu tinggi titik di permukaan objek. Titik kontrol tersebut selanjutnya dilakukan optimasi geometri jaring dan mengabaikan optimasi efisiensi alat dan biaya serta sensitivitas jaring. Optimasi geometri jaring kontrol pemantauan gerakan massa tanah merupakan langkah awal pembangunan jaring kontrol pemantauan secara real-time dan kontinu. Optimasi tersebut dilakukan untuk memberikan gambaran ketelitian koordinat saat melakukan pengukuran untuk pemantauan gerakan massa tanah di segmen $\mathrm{km} \mathrm{15,9.} \mathrm{Jaring} \mathrm{kontrol} \mathrm{pemantauan}$ didesain secara geometrik dengan kombinasi dari teknologi Global Navigation Satellite System (GNSS) dan Robotic Total Station (RTS). Teknologi GNSS digunakan karena memiliki tingkat ketelitian dan kepresisian yang tinggi serta tidak memerlukan intervisibilitas antar titik (Erol dkk., 2002). Teknologi RTS digunakan untuk memantau pergerakan struktur jembatan akibat pergerakan massa tanah di sekitar segmen km 15,9 Saluran Induk Kalibawang. Optimasi jaring GNSS dilakukan berdasarkan variasi jumlah baseline. Optimasi jaring RTS dilakukan berdasarkan variasi jarak antar titik prisma target. Optimasi geometri jaring kontrol ini dilakukan dengan data simulasi yang diturunkan dari data orthophoto dengan kriteria optimal yang terdiri atas kriteria presisi dan keandalan. Hasil perhitungan optimasi geometri jaring digunakan untuk memantau gerakan massa tanah secara real-time dan kontinu dengan gabungan teknologi GNSS dan RTS.

\section{Data dan Metodologi}

\subsection{Data dan Lokasi}

Penelitian dilakukan di Jembatan Talang Bowong, Saluran Induk Kalibawang, Kabupaten Kulon Progo, Provinsi Daerah Istimewa Yogyakarta dengan data orthophoto daerah Saluran Induk Kalibawang. Lokasi penelitian Saluran Induk Kalibawang segmen km 15,9, seperti ditunjukkan pada Gambar 1. Data yang digunakan pada penelitian ini yaitu data orthophoto tahun 2020 daerah segmen $\mathrm{km} \mathrm{15,9}$ Saluran Induk Kalibawang, Kabupaten Kulon Progo, Daerah Istimewa Yogyakarta serta data spesifikasi ketelitian alat GNSS Leica seri GM30 dan RTS Leica seri TS16 1".

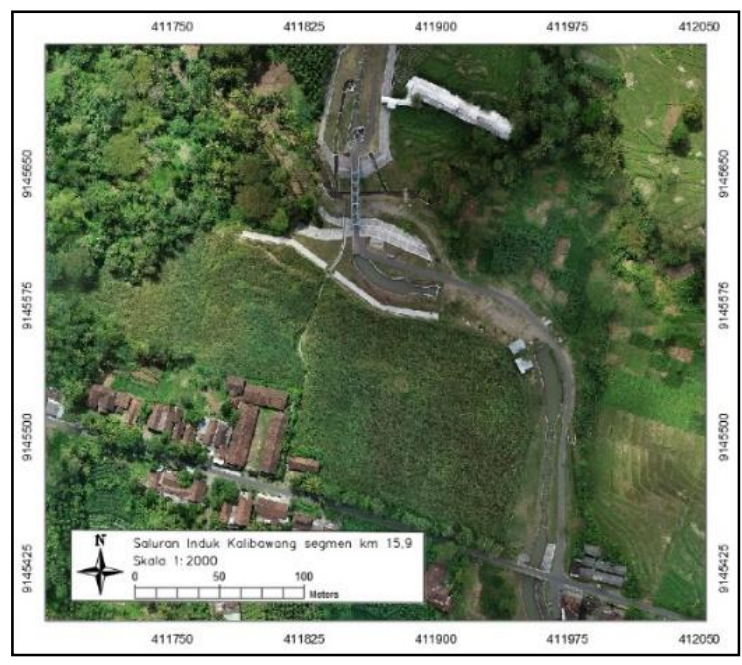

Gambar 1 Orthophoto Saluran Induk Kalibawang segmen km 15,9

\subsection{Metodologi}

Penelitian ini dilakukan dengan data simulasi yang diturunkan dari orthophoto. Data yang didapatkan berupa data koordinat dalam sistem koordinat Universal Transverse Mercator (UTM). Optimasi jaring GNSS dan RTS dilakukan secara terpisah karena pembuatan desain jaring GNSS dilakukan berdasarkan variasi jumlah baseline dan tidak melakukan pemindahan titik kontrol sedangkan pembuatan desain jaring RTS dilakukan berdasarkan variasi jarak antar titik prisma target dan dengan metode pengikatan ke muka. Proses estimasi nilai-nilai parameter dilakukan dengan perataan hitung kuadrat terkecil metode parameter. Prinsip perhitungan ini yaitu menghitung jumlah kuadrat dari koreksi yang diberikan pada ukuran adalah minimum dengan nilai besaran pengamatan pada persamaan tersebut merupakan fungsi parameter (Ghilani, 2010). Proses estimasi dengan hitung kuadrat terkecil 
metode parameter dilakukan penyusunan matriks konfigurasi $(\mathrm{A})$, matriks bobot $(\mathrm{P})$, matriks parameter $(\mathrm{X})$, dan matriks pengamatan (L). Setiap baseline memiliki tiga komponen vektor baseline yaitu $\Delta \mathrm{E}, \Delta \mathrm{N}$, dan $\Delta \mathrm{h}$. Komponen vektor baseline jaring GNSS disajikan pada persamaan (1) s.d. (3). Jumlah persamaan ditentukan berdasarkan jumlah komponen vektor baseline dalam suatu jaring.

$$
\begin{aligned}
& \Delta E_{i j}+V_{i j}=E_{j}-E_{i} \\
& \Delta N_{i j}+V_{i j}=N_{j}-N_{i} \\
& \Delta h_{i j}+V_{i j}=h_{j}-h_{i}
\end{aligned}
$$

Dalam hal ini:

$\begin{array}{ll}\Delta \mathrm{E}_{\mathrm{ij}} & : \text { komponen vektor baseline } \mathrm{E}_{\mathrm{i}} \text { ke } \mathrm{E}_{\mathrm{j}} \\ \Delta \mathrm{N}_{\mathrm{ij}} & \text { : komponen vektor baseline } \mathrm{N}_{\mathrm{i}} \text { ke } \mathrm{N}_{\mathrm{j}} \\ \Delta \mathrm{h}_{\mathrm{ij}} & : \text { komponen vektor baseline } \mathrm{h}_{\mathrm{i}} \text { ke } \mathrm{h}_{\mathrm{j}} \\ \mathrm{E}_{\mathrm{i}}, \mathrm{N}_{\mathrm{i}}, \mathrm{h}_{\mathrm{i}} & \text { : nilai koordinat titik referensi } \\ \mathrm{E}_{\mathrm{j}}, \mathrm{N}_{\mathrm{j}}, \mathrm{h}_{\mathrm{j}} & \text { : nilai koordinat titik yang diamat } \\ \mathrm{V}_{\mathrm{ij}} & \text { : nilai residu atau koreksi pengamatan }\end{array}$

Komponen baseline jaring RTS disajikan pada persamaan (4) s.d. (6).

$$
\begin{gathered}
s_{\mathrm{ij}}=\sqrt{\left(E_{\mathrm{j}}-E_{\mathrm{i}}\right)^{2}+\left(N_{\mathrm{j}}-N_{\mathrm{i}}\right)^{2}+\left(h_{\mathrm{j}}-h_{\mathrm{i}}\right)^{2}} \\
\alpha_{\mathrm{ij}}=\arctan \left(\frac{N_{\mathrm{j}}-N_{\mathrm{i}}}{E_{\mathrm{j}}-E_{\mathrm{i}}}\right) \\
Z_{\mathrm{ij}}=\frac{\sqrt{\left(E_{\mathrm{j}}-E_{\mathrm{i}}\right)^{2}+\left(N_{\mathrm{j}}-N_{\mathrm{i}}\right)^{2}}}{\tan \left(h_{\mathrm{j}}-h_{\mathrm{i}}+h_{\mathrm{t}}\right)}
\end{gathered}
$$

Dalam hal ini:

$\begin{array}{ll}\mathrm{S}_{\mathrm{ij}} & : \text { jarak miring } \\ \alpha_{\mathrm{ij}} & : \text { sudut azimut } \\ \mathrm{Z}_{\mathrm{ij}} & : \text { sudut zenit } \\ \mathrm{E}_{\mathrm{j}}, \mathrm{N}_{\mathrm{j}}, \mathrm{h}_{\mathrm{j}} & : \text { koordinat titik kontrol RTS } \\ \mathrm{E}_{\mathrm{i}}, \mathrm{N}_{\mathrm{i}}, \mathrm{h}_{\mathrm{i}} & : \text { koordinat titik prisma target } \\ \mathrm{h}_{\mathrm{t}} & : \text { tinggi alat RTS }\end{array}$

Komponen vektor baseline digunakan dalam perhitungan bobot ukuran. Perhitungan desain jaring GNSS pada penelitian ini menggunakan nilai varian sebesar \pm (6 $\mathrm{mm}+1 \mathrm{ppm}$ ) dikalikan vektor baseline. Nilai varian ini didapatkan dari GNSS Leica seri GM30. Perhitungan desain jaring RTS pada penelitian ini menggunakan nilai varian jarak sebesar $\pm(1 \mathrm{~mm}+1,5 \mathrm{ppm})$, nilai varian sudut horizontal dan vertikal sebesar 0,3 mgon. Nilai varian ini didapatkan dari RTS Leica seri TS16 1". Desain matriks P jaring GNSS sebagai berikut.

$$
{ }_{n} P_{n}=\left[\begin{array}{ccc}
C_{x 1}^{-1} & 0 & 0 \\
0 & \cdots & 0 \\
0 & 0 & C_{x n}^{-1}
\end{array}\right]
$$

$C_{x}$ merupakan matriks varian-kovarian komponen vektor baseline GNSS.

$$
C_{x}=\left[\begin{array}{ccc}
\sigma_{\Delta E_{n}}^{2} & \sigma_{\Delta E_{n} \Delta N_{n}} & \sigma_{\Delta E_{n} \Delta h_{n}} \\
\sigma_{\Delta E_{n} \Delta N_{n}} & \sigma_{\Delta N_{n}}^{2} & \sigma_{\Delta N_{n} \Delta h_{n}} \\
\sigma_{\Delta E_{n} \Delta h_{n}} & \sigma_{\Delta N_{n} \Delta h_{n}} & \sigma_{\Delta h_{n}}^{2}
\end{array}\right]
$$

Matriks A merupakan matriks turunan persamaan observasi terhadap parameter. Jumlah baris pada matriks A menunjukkan banyaknya persamaan observasi dan jumlah kolom pada matriks A menunjukkan jumlah parameter. Desain matriks A jaring GNSS sebagai berikut.

$$
{ }_{n} A_{u}=\left[\begin{array}{lllllll}
\frac{\partial l_{1}}{\partial E_{1}} & \frac{\partial l_{1}}{\partial N_{1}} & \frac{\partial l_{1}}{\partial h_{1}} & \cdots & \frac{\partial l_{n}}{\partial E_{u}} & \frac{\partial l_{n}}{\partial N_{u}} & \frac{\partial l_{n}}{\partial h_{u}} \\
\frac{\partial l_{2}}{\partial E_{1}} & \frac{\partial l_{2}}{\partial N_{1}} & \frac{\partial l_{2}}{\partial h_{1}} & \cdots & \frac{\partial l_{n}}{\partial E_{u}} & \frac{\partial l_{n}}{\partial N_{u}} & \frac{\partial l_{n}}{\partial h_{u}} \\
\vdots \\
\frac{\partial l_{n}}{\partial E_{1}} & \frac{\partial l_{n}}{\partial N_{1}} & \frac{\partial l_{n}}{\partial h_{1}} & \cdots & \frac{\partial l_{n}}{\partial E_{u}} & \frac{\partial l_{n}}{\partial N_{u}} & \frac{\partial l_{n}}{\partial h_{u}}
\end{array}\right]
$$

Dalam hal ini:

n : jumlah persamaan

u : jumlah parameter

Matriks matriks L didapatkan dari perhitungan selisih nilai pendekatan pengamatan dengan nilai pengamatan serta matriks X dapat dihitung dengan persamaan (9).

$$
X=-\left(A^{T} P A\right)^{-1} A^{T} P L
$$

Dalam hal ini:

$X \quad$ : matriks koreksi parameter

$A \quad$ : matriks turunan fungsi pengamatan terhadap parameter

$P \quad$ : matriks bobot

$L \quad$ :selisih nilai pengamatan dengan nilai pendekatan Optimasi jaring 112 kontrol 112 bertujuan untuk mendapatkan jaring yang paling optimal dari pengukuran 112titik antar stasiun. Penentuan desain jaring yang paling optimal bergantung pada parameter kriteria optimasi. Kriteria optimasi dapat dilihat dari segi presisi, keandalan, dan ekonomi (Kuang, 1996). Penelitian ini berfokus pada kriteria presisi dan keandalan. Kriteria presisi menjelaskan kepresisian pengukuran berpengaruh terhadap hasil estimasi melalui geometri dari jaring. Kriteria presisi suatu jaring kontrol didapatkan dari perataan dengan hitung kuadrat terkecil metode parameter yaitu dari nilai eigen matriks varian-kovarian. Analisis optimasi fungsi scalar dari kriteria optimasi presisi yang digunakan yaitu, AOptimality, D-Optimality, E-Optimality, S-Optimality, dan IOptimality dari nilai eigen masing-masing proses (Grafarend, 1974) dalam (Kuang, 1996). Menurut Kuang (1996), persamaan (10) s.d. (14) untuk mencari nilai kriteria presisi.

$$
\begin{aligned}
& \text { A-Optimality } \\
& \quad f=\operatorname{trace}\left(C_{x}\right)=\lambda_{1}+\lambda_{2}+\cdots+\lambda_{h}=\min \\
& \text { D-Optimality } \\
& \quad f=\operatorname{Det}\left(C_{x}\right)=\lambda_{1} * \lambda_{2} * \ldots * \lambda_{h}=\min
\end{aligned}
$$

\section{E-Optimality}

$$
\lambda_{\text {maks }}=\min
$$

\section{S-Optimality}

$$
\left(\lambda_{\text {maks }} \lambda_{\text {min }}\right)=\min
$$




\section{I-Optimality}

$$
\frac{1-\lambda_{\min }}{\lambda_{\min }}=\min
$$

Dalam hal ini:

$\mathrm{C}_{\mathrm{x}} \quad$ : matriks varian-kovarian pengamatan

$\lambda \quad$ : nilai eigen matriks $C_{x}$

Matriks varian-kovarian pengamatan dapat dihitung menggunakan persamaan (15).

$$
C_{x}=\left(A^{T} P A\right)^{-1}
$$

Dalam hal ini:

$P \quad$ : matriks bobot

A : matriks turunan fungsi pengamatan terhadap parameter

Kriteria keandalan digunakan untuk menentukan jaring yang optimal selain kriteria presisi (Amiri-Simkooei, dkk., 2001). Kriteria keandalan menjelaskan jaring bereaksi terhadap bias yang kecil dari pengukuran. Kriteria keandalan pada jaring kontrol bergantung pada geometri suatu jaring, yaitu matriks konfigurasi dan matriks bobot suatu pengukuran. Kriteria keandalan bertujuan untuk mereduksi kesalahan kasar dari suatu pengamatan serta untuk memperkecil efek dari ketidaktepatan dalam melakukan estimasi parameter. Kriteria keandalan terbagi menjadi dua jenis, yaitu keandalan dalam dan keandalan luar. Keandalan luar dari jaring kontrol berkaitan dengan efek dari kesalahan yang tidak terdeteksi pada parameter terestimasi. Keandalan dalam dari jaring kontrol merepresentasikan kualitas jaring yang mengacu pada batas minimal dari kesalahan kasar yang dapat dideteksi pada sejumlah pengamatan untuk nilai probabilitas yang diberikan terhadap kesalahan (Kuang, 1991). Nilai kriteria keandalan didapatkan dari perataan dengan hitung kuadrat terkecil metode parameter yaitu dari matriks kofaktor residu. Menurut Yalçinkaya and Teke (2006) persamaan (16) s.d. (18) untuk mencari nilai kriteria keandalan.

\section{Redundansi Individu}

$$
Z=r_{j}=\left(Q_{v v}\right) P_{j}
$$

\section{Keandalan Dalam}

$$
Z=\left|\Delta_{o j}\right|=m_{0} \sqrt{w_{0} / P_{j} r_{j}}
$$

\section{Keandalan Luar}

$$
Z=\delta_{o j^{2}}=\left(\frac{1-r_{j}}{r_{j}}\right) \cdot w_{0}
$$

Dalam hal ini:

$\mathrm{P}_{\mathrm{j}} \quad$ : matriks bobot dari persamaan

$\mathrm{Q}_{\mathrm{vv}}$ : matriks kofaktor residu

A : matriks turunan fungsi pengamatan terhadap parameter

$\mathrm{m}_{0}$ : simpangan baku dari unit bobot

$\mathrm{w}_{0}$ : standar batas bawah untuk parameter

Matriks kofaktor residu dapat dihitung dengan persamaan (19).

$$
Q_{v v}=P^{-1}-A\left(A^{T} P A\right)^{-1} A^{T}
$$

Dalam hal ini:

$P \quad$ : matriks bobot

$A \quad$ : matriks turunan fungsi pengamatan terhadap parameter

Jaring GNSS dan RTS didesain dengan perangkat lunak Autocad Civil 3D 2020. Proses estimasi dengan perataan hitung kuadrat terkecil metode parameter serta perhitungan kriteria optimasi jaring GNSS dan RTS menggunakan perangkat lunak Matlab 2017b. Pemilihan jaring yang optimal dilakukan dengan membandingkan nilai hasil perhitungan kriteria presisi dan kriteria keandalan jaring GNSS dan RTS. Desain jaring dikatakan sudah optimal jika ditinjau dari kriteria presisi nilai AOptimality, D-Optimality, E-Optimality, S-Optimality, dan IOptimality memiliki nilai paling minimal jika dibandingkan dengan desain jaring lainnya. Selain itu, desain jaring dikatakan optimal apabila ditinjau dari kriteria keandalan yang terdiri atas nilai keandalan dalam dan keandalan luar memiliki nilai yang tidak melebihi nilai kritis yang telah ditentukan (Yalçinkaya and Teke, 2006).

\section{Hasil dan Pembahasan}

\subsection{Desain jaring GNSS}

Pembuatan desain jaring GNSS dilakukan dengan membuat baseline yang menghubungkan antara satu titik kontrol dengan titik kontrol lainnya. Desain jaring GNSS pada penelitian ini dibentuk dari jaring yang paling sederhana hingga jaring yang paling kompleks. Jaring GNSS yang paling sederhana yaitu jaring yang memiliki jumlah baseline paling sedikit sedangkan jaring GNSS yang paling kompleks yaitu jaring yang memiliki jumlah baseline yang paling banyak. Setiap desain jaring memiliki variasi jumlah baseline yang berbeda. Hal ini dikarenakan alat yang digunakan dalam penelitian selanjutnya berjumlah enam sehingga dalam penelitian ini hanya dapat melakukan penambahan jumlah ukuran baseline. Jumlah desain jaring GNSS yang dibentuk sebanyak empat jaring dengan enam titik kontrol GNSS dimana terdapat satu titik kontrol fixed (titik ikat).

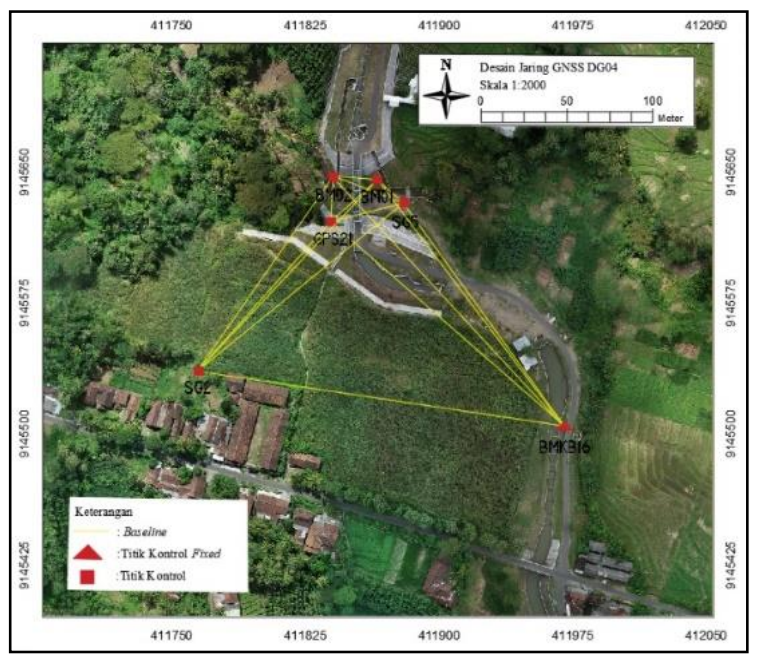

Gambar 2 Desain jaring GNSS DG04 
Gambar 2 menunjukkan desain jaring GNSS paling kompleks yang terbentuk dari enam titik kontrol yaitu BMKB16, SG2, GPS21, SG5, BM01, dan BM02. BMKB16 merupakan titik kontrol fixed (titik ikat) karena lokasi titik tersebut berada di luar area yang terdeformasi.

\subsection{Kepresisian jaring GNSS}

Kriteria presisi menjelaskan kepresisian pengukuran berpengaruh terhadap hasil estimasi melalui geometri dari jaring. Kriteria presisi suatu jaring kontrol diperoleh dari nilai eigen pada matriks varian-kovarian parameter koordinat titik. Analisis optimasi fungsi 114 skalar dari kriteria optimasi presisi yang digunakan yaitu, A-Optimality, D-Optimality, E-Optimality, S-Optimality, dan I-Optimality dari nilai eigen masing-masing proses. Kualitas jaring kontrol yang terbaik memiliki nilai hasil perhitungan kriteria presisi yang paling kecil atau minimum. Desain jaring GNSS pada penelitian ini dibentuk dengan enam titik yaitu BMKB16, SG2, SG5, GPS21, BM01, dan BM02. Titik BMKB16 merupakan titik kontrol fixed (titik ikat). Perbandingan hasil perhitungan kriteria presisi pada desain jaring GNSS DG01, DG02, DG03, dan DG04 ditunjukkan pada Tabel 1.

Tabel 1 Kriteria presisi jaring GNSS

\begin{tabular}{ccc}
\hline & Desain jaring GNSS & DG01 \\
\cline { 2 - 3 } & A-Optimality & 0,055 \\
& D-Optimality & $2,86 \mathrm{E}-40$ \\
& E-Optimality & 0,012 \\
Jumlah baseline : 10 & S-Optimality & 0,011 \\
& I-Optimality & 988,272 \\
\hline & Desain jaring GNSS & DG02 \\
\cline { 2 - 3 } & A-Optimality & 0,036 \\
& D-Optimality & $1,36 \mathrm{E}-41$ \\
& E-Optimality & 0,006 \\
Jumlah baseline : 12 & S-Optimality & 0,005 \\
& I-Optimality & 1000,377 \\
\hline & Desain jaring GNSS & DG03 \\
\cline { 2 - 3 } & A-Optimality & 0,032 \\
& D-Optimality & $7,89 \mathrm{E}-43$ \\
& E-Optimality & 0,006 \\
Jumlah baseline : 14 & S-Optimality & 0,005 \\
& I-Optimality & 1006,155 \\
\hline & Desain jaring GNSS & DG04 \\
\cline { 2 - 3 } & A-Optimality & 0,030 \\
& D-Optimality & $2,16 \mathrm{E}-43$ \\
& E-Optimality & 0,006 \\
& S-Optimality & 0,005 \\
& I-Optimality & 1009,117 \\
\hline
\end{tabular}

Tabel 1 dapat dilihat bahwa mayoritas nilai kriteria presisi minimum terdapat pada desain jaring GNSS DG04 dengan nilai A-Optimality sebesar 0,030, nilai D-Optimality sebesar 2,16E-43, nilai E-Optimality sebesar 0,006, dan nilai S-Optimality sebesar 0,005. Sedangkan, nilai IOptimality minimum terdapat pada jaring DG01 dengan nilai sebesar 988,272. Mayoritas nilai kriteria presisi maksimum terdapat pada jaring DG01 dengan nilai AOptimality sebesar 0,055, nilai D-Optimality sebesar 2,86E40, nilai E-Optimality sebesar 0,012, dan nilai S-Optimality sebesar 0,011. Sedangkan, nilai I-Optimality maksimum terdapat pada jaring DG04 dengan nilai sebesar 1009,117.

Jaring DG04 merupakan jaring yang memiliki panjang baseline yang cenderung sama (homogen) dan memiliki sifat isotropi terbaik dibandingkan dengan jaring DG01, DG02, dan DG03. Nilai kriteria presisi juga dipengaruhi oleh penambahan jumlah baseline dalam suatu jaring, semakin banyak jumlah baseline maka nilai kriteria presisi minimum dan sebaliknya. Jaring DG04 memiliki jumlah baseline paling banyak dibandingkan dengan jaring lainnya. Oleh karena itu, desain jaring GNSS DG04 merupakan desain jaring yang optimal karena memiliki nilai kriteria presisi yang minimum dibandingkan dengan desain jaring lainnya.

\subsection{Keandalan jaring GNSS}

Kriteria keandalan bertujuan untuk mereduksi kesalahan kasar dari suatu pengamatan serta untuk memperkecil efek dari ketidaktepatan dalam melakukan estimasi parameter. Kriteria keandalan pada jaring kontrol bergantung pada geometri suatu jaring yaitu matriks konfigurasi dan matriks bobot suatu pengukuran. Analisis kriteria keandalan menggunakan hasil perhitungan redundansi individu, keandalan dalam, dan keandalan luar pada setiap desain jaring GNSS

Tabel 2 Nilai rata-rata kriteria keandalan jaring GNSS

\begin{tabular}{ccc}
\hline & Desain jaring GNSS & DG01 \\
\cline { 2 - 3 } & $\begin{array}{c}\text { Redundansi individu } \\
\text { Keandalan dalam }\end{array}$ & 0,500 \\
& 0,551 \\
Jumlah baseline $: 10$ & Keandalan luar & 5,020 \\
\hline & Desain jaring GNSS & DG02 \\
\cline { 2 - 3 } & Redundansi individu & 0,583 \\
Jumlah baseline $: 12$ & Keandalan dalam & 0,554 \\
& Keandalan luar & 4,606 \\
\hline & Desain jaring GNSS & DG03 \\
\cline { 2 - 3 } & Redundansi individu & 0,643 \\
Jumlah baseline $: 14$ & Keandalan dalam & 0,555 \\
& Keandalan luar & 4,274 \\
\hline & Desain jaring GNSS & DG04 \\
\cline { 2 - 3 } & Redundansi individu & 0,667 \\
& Keandalan dalam & 0,557 \\
Jumlah baseline $: 15$ & Keandalan luar & 4,153 \\
\hline
\end{tabular}

Tabel 2 merupakan nilai rata-rata kriteria keandalan jaring GNSS yang terdiri dari kriteria redundansi individu, keandalan dalam, dan keandalan luar. Tabel 2 menunjukkan semua desain jaring GNSS memiliki nilai hasil perhitungan yang memenuhi semua kriteria keandalan. Hal itu berarti semua desain jaring GNSS yang dibentuk dapat mendeteksi adanya kesalahan kasar, mempunyai sensitivitas tinggi adanya kesalahan tidak acak, dan mempunyai pengaruh terhadap adanya kesalahan tidak acak yang terdeteksi. Jaring DG04 merupakan jaring yang 
paling handal jika ditinjau dari kriteria redundansi individu dan keandalan luar. Jaring DG04 memiliki kemampuan yang paling tinggi untuk mendeteksi adanya kesalahan kasar serta memiliki pengaruh yang paling rendah terhadap adanya kesalahan tidak acak yang terdeteksi dalam jaring. Sedangkan, jaring DG01 merupakan jaring yang paling handal jika ditinjau dari kriteria keandalan dalam, sehingga jaring DG01 memiliki sensitivitas yang paling tinggi terhadap kesalahan tidak acak. Tabel 2 juga dapat dilihat bahwa penambahan baseline pada desain jaring GNSS memiliki pengaruh dari kriteria keandalan jaring. Desain jaring GNSS yang memiliki baseline yang kompleks lebih handal daripada desain jaring GNSS yang paling sederhana.

\subsection{Desain jaring RTS}

Pembuatan desain jaring RTS dilakukan dengan baseline yang menghubungkan antara satu titik kontrol dengan titik prisma target. Titik kontrol RTS berada di sebelah kanan dan kiri Jembatan Talang Bowong. Hal ini dikarenakan adanya faktor intervisibilitas antar titik kontrol dan titik prisma target. Desain jaring RTS dibentuk dengan metode pengikatan ke muka dengan empat titik yang sudah diketahui koordinatnya melalui GNSS yang terintegrasi dengan RTS. Titik tersebut digunakan sebagai titik berdirinya RTS. Jumlah desain jaring RTS dibentuk sebanyak empat jaring dengan variasi jarak antar titik prisma target sehingga jumlah titik prisma target pada setiap desain jaring RTS berbeda. Penentuan jarak antar titik prisma target mempertimbangkan panjang jembatan karena RTS digunakan untuk memantau pergerakan struktur jembatan. Hal itu berarti jumlah baseline yang terbentuk pada setiap desain jaring RTS berbeda. Tinggi titik yang digunakan yaitu tinggi titik di permukaan objek. Desain jaring RTS terbentuk dari empat titik kontrol RTS yaitu SG5, GPS21, BM01, dan BM02.

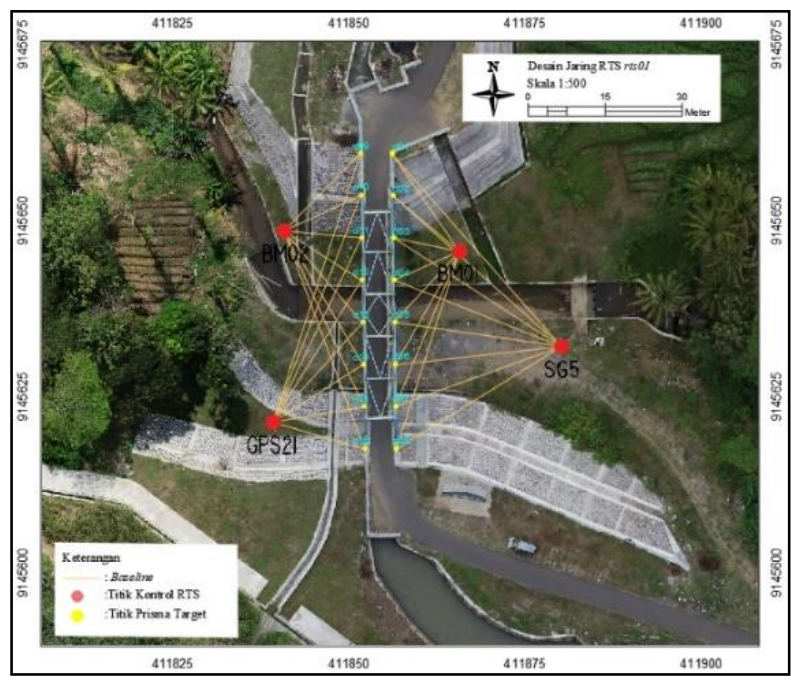

Gambar 3 Desain jaring RTS rts01

Gambar 3 menunjukkan desain jaring RTS dengan jarak antar titik prisma target paling jauh yaitu sebesar $6 \mathrm{~m}$. Setiap jaring RTS memiliki perbedaan jarak antar prisma target sebesar $1 \mathrm{~m}$. Jaring rts 01 memiliki jarak antar prisma target sebesar $6 \mathrm{~m}$, jaring rts02 sebesar $5 \mathrm{~m}$, jaring rts03 sebesar $4 \mathrm{~m}$, dan jaring rts04 sebesar $3 \mathrm{~m}$. Apabila pemantauan secara kontinu dilakukan selama 24 jam perhari, tujuh hari per-minggu maka desain jaring RTS dengan jumlah titik prisma target paling sedikit menghasilkan lebih banyak data pengukuran berulang dibandingkan dengan desain jaring RTS dengan jumlah titik prisma target paling banyak.

\subsection{Kepresisian jaring RTS}

Menurut Kuang, 1996, ukuran kualitas jaring geodesi dapat diketahui dengan ukuran presisi berupa fungsi skalar yang didapatkan dari elemen matriks varian-kovarian koordinat. Hal itu berarti bahwa perhitungan nilai kriteria presisi tidak hanya dapat dilakukan pada jaring GNSS, namun dapat diterapkan pada jaring RTS. Analisis optimasi fungsi skalar dari kriteria optimasi presisi pada penelitian ini yaitu, A-Optimality, D-Optimality, E-Optimality, SOptimality, dan I-Optimality dari nilai eigen masing-masing proses. Kualitas jaring yang terbaik memiliki nilai hasil perhitungan kriteria presisi yang paling kecil atau minimum. Perbandingan nilai hasil perhitungan kriteria presisi pada desain jaring RTS rts01, rts02, rts03, dan $r$ ts04 ditunjukkan pada Tabel 3.

Tabel 3 Kriteria presisi jaring RTS

\begin{tabular}{|c|c|c|}
\hline \multirow{6}{*}{$\begin{array}{c}\text { Jumlah prisma } \\
\text { target : } 16\end{array}$} & Desain jaring RTS & rts01 \\
\hline & A-Optimality & 0,037 \\
\hline & D-Optimality & 0 \\
\hline & E-Optimality & 0,002 \\
\hline & S-Optimality & 0,002 \\
\hline & I-Optimality & 2730,323 \\
\hline \multirow{6}{*}{$\begin{array}{c}\text { Jumlah prisma } \\
\text { target : } 20\end{array}$} & Desain jaring RTS & rts02 \\
\hline & A-Optimality & 0,047 \\
\hline & D-Optimality & 0 \\
\hline & E-Optimality & 0,002 \\
\hline & S-Optimality & 0,002 \\
\hline & I-Optimality & 2798,319 \\
\hline \multirow{6}{*}{$\begin{array}{c}\text { Jumlah prisma } \\
\text { target : } 24\end{array}$} & Desain jaring RTS & rts03 \\
\hline & A-Optimality & 0,056 \\
\hline & D-Optimality & 0 \\
\hline & E-Optimality & 0,002 \\
\hline & S-Optimality & 0,002 \\
\hline & I-Optimality & 2818,374 \\
\hline \multirow{6}{*}{$\begin{array}{c}\text { Jumlah prisma } \\
\text { target : } 32\end{array}$} & Desain jaring RTS & rts04 \\
\hline & A-Optimality & 0,074 \\
\hline & D-Optimality & 0 \\
\hline & E-Optimality & 0,002 \\
\hline & S-Optimality & 0,002 \\
\hline & I-Optimality & 2830,547 \\
\hline
\end{tabular}

Tabel 3 menunjukkan mayoritas nilai kriteria presisi minimum terdapat pada desain jaring RTS rts01 dengan nilai A-Optimality sebesar 0,037, nilai E-Optimality sebesar 
0,002, nilai S-Optimality sebesar 0,002, dan nilai IOptimality sebesar 2730,323. Mayoritas nilai kriteria presisi maksimum terdapat pada jaring rts01 dengan dengan nilai A-Optimality sebesar 0,074, nilai E-Optimality sebesar 0,002, nilai S-Optimality sebesar 0,002, dan nilai IOptimality sebesar 2830,323. Nilai kriteria presisi yang paling mencerminkan keoptimalan suatu jaring RTS yaitu nilai A-Optimality dan D-Optimality karena dalam perhitungannya melibatkan seluruh nilai eigen matriks varian-kovarian pengamatan. Jaring rts01 merupakan jaring yang memiliki panjang baseline yang cenderung sama (homogen) serta memiliki sifat fisik yang sama ke semua arah (isotropi) terbaik dibandingkan jaring $r t s 02$, rts03, dan rts04.

\subsection{Keandalan jaring RTS}

Kriteria keandalan seperti redundansi individu, keandalan dalam, dan keandalan luar dapat digunakan untuk memilih desain jaring geodetik optimal yang melibatkan pemilihan lokasi dan jumlah titik jaring, serta pemilihan jumlah dan bobot pengamatan. Oleh karena itu, perhitungan kriteria keandalan tidak hanya dilakukan pada jaring GNSS, namun dapat dilakukan pada jaring RTS. Tabel 4 merupakan nilai rata-rata kriteria keandalan jaring RTS yang terdiri atas kriteria redundansi individu, keandalan dalam, dan keandalan luar.

Tabel 4 Nilai rata-rata kriteria keandalan jaring GNSS

\begin{tabular}{|c|c|c|}
\hline & Desain jaring RTS & rts01 \\
\hline & Redundansi individu & 0,500 \\
\hline \multirow{2}{*}{$\begin{array}{l}\text { Jumlah prisma } \\
\text { target : } 16\end{array}$} & Keandalan dalam & 0,122 \\
\hline & Keandalan luar & 2,292 \\
\hline \multirow{4}{*}{$\begin{array}{l}\text { Jumlah prisma } \\
\text { target : } 20\end{array}$} & Desain jaring RTS & rts02 \\
\hline & Redundansi individu & 0,500 \\
\hline & Keandalan dalam & 0,127 \\
\hline & Keandalan luar & 2,371 \\
\hline \multirow{4}{*}{$\begin{array}{c}\text { Jumlah prisma } \\
\text { target : } 24\end{array}$} & Desain jaring RTS & rts03 \\
\hline & Redundansi individu & 0,500 \\
\hline & Keandalan dalam & 0,130 \\
\hline & Keandalan luar & 2,444 \\
\hline & Desain jaring RTS & rts04 \\
\hline & Redundansi individu & 0,500 \\
\hline \multirow{2}{*}{$\begin{array}{c}\text { Jumlah prisma } \\
\text { target : } 32\end{array}$} & Keandalan dalam & 0,135 \\
\hline & Keandalan luar & 2,520 \\
\hline
\end{tabular}

Berdasarkan Tabel 4, semua desain jaring RTS memiliki nilai hasil perhitungan yang memenuhi semua kriteria keandalan. Hal itu berarti semua desain jaring RTS dapat mendeteksi adanya kesalahan kasar, mempunyai sensitivitas tinggi adanya kesalahan tidak acak, dan mempunyai pengaruh terhadap adanya kesalahan tidak acak yang terdeteksi. Semua desain jaring RTS yang dibentuk memiliki nilai redundansi yang sama sehingga semua desain jaring RTS memiliki kemampuan yang sama tinggi untuk mendeteksi adanya kesalahan kasar. Jaring rts01 merupakan jaring yang paling handal jika ditinjau dari kriteria keandalan dalam dan keandalan luar. Hal itu berarti jaring rts01 memiliki sensitivitas yang paling tinggi terhadap kesalahan tidak acak serta memiliki pengaruh yang paling rendah terhadap adanya kesalahan tidak acak yang tidak terdeteksi dalam jaring. Tabel III.21 juga dapat dilihat bahwa penambahan jumlah titik prisma target pada desain jaring RTS berpengaruh terhadap kriteria keandalan jaring. Desain jaring RTS yang memiliki jumlah titik prisma target paling sedikit lebih handal daripada desain jaring RTS yang banyak. Berdasarkan penelitian yang dilakukan oleh (Bergkvist, 2015) yang mengatakan bahwa jaring RTS paling optimal memiliki jumlah titik prisma target paling banyak. Pemantauan gerakan massa tanah secara kontinu dilakukan selama 24 jam per-hari, tujuh hari per-minggu sehingga desain jaring RTS dengan jumlah titik prisma target paling sedikit menghasilkan lebih banyak data pengukuran berulang dibandingkan dengan desain jaring RTS dengan jumlah titik prisma target paling banyak.

\section{Kesimpulan}

Desain jaring GNSS yang paling optimal yaitu jaring DG04. Hal ini ditunjukkan dari nilai kriteria presisi dan keandalan luar paling kecil serta nilai kriteria redundansi individu paling besar. Jaring DG04 memiliki baseline paling kompleks dibandingkan dengan desain jaring GNSS lainnya. Desain jaring RTS yang paling optimal yaitu jaring rts01. Hal ini ditunjukkan dari nilai kriteria presisi, keandalan dalam, dan keandalan luar paling kecil serta nilai kriteria redundansi individu paling besar. Jaring rts01 memiliki jumlah titik prisma target paling banyak dibandingkan dengan desain jaring RTS lainnya. Hal itu berarti implementasi instalasi jaring pemantauan deformasi kontinu dengan kombinasi alat GNSS dan RTS di segmen $\mathrm{km}$ 15,9 sebaiknya menggunakan desain jaring GNSS DG04 dan desain jaring RTS rts01.

\section{Pernyataan Konflik Kepentingan}

Penulis menyatakan tidak ada konflik kepentingan dalam artikel ini.

\section{Referensi}

Amiri-Simkooei, A. R., (2001). Strategy for Designing Geodetic Network with High Realibility and Geometrical Strength Criteria. J. Surv. Eng., 127(3), 104-117.

Amiri-Simkooei, A. R.; Asgari, J.; Zangeneh-Nejad, F.; dan Zaminpardaz, S., (2012). Basic Concepts of 
Optimization and Design of Geodetic Networks. https://doi.org/10.1061/(ASCE)SU.1943-

5428.0000081

Anonim, (2020). Leica TS16 Total Station - Survey it. https://leica-geosystems.com/products/totalstations/robotic-total-stations/leica-ts16 (akses tanggal 20 November 2020).

Bergkvist, J., (2015). Optimal Design of Network for Control of Total Station Instruments.

DPUPKP, (2020). Sistem Irigasi Kalibawang, Penyedia Irigasi Utama Kulon Progo. https://dpu.kulonprogokab.go.id/detil/379/sistemirigasi-kalibawang-penyedia-irigasi-utama-kulonprogo (akses tanggal 30 November 2020).

Dwidjaka, A., (2006). Pengaruh Variasi Kadar Air terhadap Deformasi. Disertasi, Teknik Sipil, Universitas Gadjah Mada.

Erol, S., Erol, B., dan Ayan, T., (2002), A General Review of the Deformation Monitoring Techniques and a Case Study: Analysing Deformations using GPS/Levelling, ISPRS Congress.

Ghilani, C.D., (2010). Adjustment Computations: Spatial Data Analysis: $\quad 5^{\text {th }}$ Edition, https://doi.org/10.1002/9780470586266.

Grafarend, E.W., (1974), Optimization of Geodetic Networks, Bolletino di Geodesia a Science Affini, 351406.

Kuang, S., (1991). Optimization and Design of Deformation Monitoring Schemes. PhD. dissertation. Tech. Rep. 157, Dept. of Surveying Engineering, Univ. of New Brunswick, Fredericton, NB, Canada.

Kuang, S., (1996). Geodetic Network Analysis and Optimal Design: Concepts and Applications. Ann Arbor Press, Chelsea Michigan.

Leick, A., (2004), GPS Satellite Surveying, 3 ${ }^{\text {rd }}$ Edition, John Wiley and Sons Inc, Hoboken, New Jersey.

Ma'ruf, B., (2015). Pola Geometri Rayapan Tanah di Segmen Km 15,9 Saluran Irigasi Kalibawang Kulon Progo dengan Metode Kalman Filtering. Disertasi, Teknik Geologi, Universitas Gadjah Mada.

Sanjaya, M.D.A., (2017). Evaluasi Aspek Geometrik Jaring Kontrol GNSS dan RTS pada Pemantauan Deformasi di Kawasan Bendungan Jatigede. Tesis, Teknik Geodesi, Universitas Gadjah Mada.

Sasongko, R., (2018). Survey Rekayasa Konstruksi: Survey Rekayasa Konstruksi. Vol. 1. Malang: Polinema Press.

Song, Z., Zhao, C., Pu, H., dan Li, X., (2016). Configuration Analysis of Two-Dimensional Resection Networks. https://doi.org/10.1061/(asce)su.19435428.00003.

Wolf, P.R. dan Ghilani C.D., (2010). Adjustment Computations Statistics and Least Squares in Surveying and GIS, Jhon Wiley and Son Inc., New York.

Yalçinkaya, M. dan Teke, K., (2006). Optimization of GPS Networks with Respect to Accuracy and Reliability Criteria, 3. 